\title{
Clinical findings and unusual epidemiologic characteristics of human metapneumovirus infections in children in the region of Basel, Switzerland
}

\author{
Gurli Baer • Urs B. Schaad • Ulrich Heininger
}

Received: 6 November 2006 / Accepted: 15 January 2007 / Published online: 13 February 2007

(C) Springer-Verlag 2007

\begin{abstract}
Human metapneumovirus (hMPV) worldwide causes respiratory tract infections with features similar to those of RSV infection. We describe features of hMPV infections in children and compare some of the characteristics with those of RSV infections. From October 2004 to February 2006, 75 patients, 34 hospitalized and 41 outpatients, were diagnosed with hMPV infections by multiplex PCR applied to nasopharyngeal specimens. While hMPV was found rarely in the early phase of the study, a significant increase occurred in the second winter of the study period. Patients with hMPV infections were older than those with RSV infection; clinical characteristics were similar as was the rate of serious disease among hospitalized patients (intensive care treatment: $18 \%$ versus $8 \%$ ). In conclusion, hMPV leads to endemic and epidemic respiratory disease with features similar to those of RSV and should be considered in the differential diagnosis of upper and lower respiratory tract disease.
\end{abstract}

Keywords Human metapneumovirus (hMPV).

Respiratory tract infection (RTI) · Children

\section{Introduction}

Human metapneumovirus (hMPV) is a recently discovered paramyxovirus that is associated with acute respiratory tract infections (RTIs) in children and adults. Since its first description in 2001 [36], the virus has been further identified in patients with RTIs from all continents [1, 3,

G. Baer $\cdot$ U. B. Schaad $\cdot$ U. Heininger $(\bowtie)$

University Children's Hospital (UKBB),

P.O. Box CH-4005, Basel, Switzerland

e-mail: Ulrich.Heininger@unibas.ch
8, 9, 14, 15, 19, 21, 22, 27-34, 41]. Seroprevalence studies in the Netherlands [36], Israel [44] and Japan [11] have shown that by the age of 5 to 10 years, seropositivity reaches virtually $100 \%$. Longitudinal surveys have indicated that hMPV has a seasonal distribution similar to respiratory syncytial virus (RSV) and influenza viruses $[15,18,34,42]$.

In October 2004, a reverse-transcriptase-polymerase chain-reaction (RT-PCR) assay was added to the panels of multiplex PCR in our laboratory to test nasopharyngeal aspirates from in- and outpatients with RTIs for the presence of respiratory pathogens [25]. Whereas only a small number of samples tested positive for hMPV in the first winter season after its introduction, we observed a remarkable increase of hMPV infections during the following winter season (October 2005 to February 2006). Here we present demographic and clinical features of hMPV infections in children that, to the best of our knowledge, is the first such report from Switzerland. Further, we compare some of the observed epidemiologic characteristics with those of RSV infections that were diagnosed during the same time period.

\section{Materials and methods}

Study subjects

Our microbiological laboratories provide a broad range of diagnostic services for in- and outpatients of our children's hospital. In addition, several pediatricians in the close vicinity take advantage of our services. From 11 October 2004 onwards, a RT-PCR for detection of hMPV was performed in nasopharyngeal aspirates (NP) sent to our laboratory in addition to the use of a previously established 
multiplex PCR for detection of RSV, parainfluenza virus types 1 and 3 , influenza A and B, and adenovirus. All assays had undergone comprehensive in-house evaluation before their introduction. NP were obtained from hospitalized patients as well as outpatients with acute RTIs according to standard clinical care in our institution and collaborating private pediatric offices. Laboratory personnel were unaware of any clinical information on the respective patients.

Clinical information (based on a standardized questionnaire) and laboratory data were abstracted from the medical records of hospitalized patients retrospectively in March 2006. For outpatients, questionnaires were sent to the pediatrician or practitioner who had collected the NP specimens. Specifically, demographic characteristics (age, gender, prematurity and underlying chronic diseases), onset of symptoms, duration of illness, clinical signs and symptoms, medication and the final clinical diagnosis were collected.

The study protocol was approved by the University of Basel Medical Faculty's ethical commission. Informed consent was obtained from the patients' parents.

\section{Case definition}

Upper respiratory tract infection (URTI) was diagnosed in the presence of characteristic signs or symptoms of rhinitis, pharyngitis, conjunctivitis or acute otitis media. Children with further signs or symptoms of pneumonia, bronchitis or bronchiolitis were diagnosed to have lower respiratory tract infection (LRTI).

\section{Laboratory investigations}

NP specimens were placed into transport medium $(0.9 \%$ sterile sodium-chloride solution), sent to the laboratory immediately and stored at $4^{\circ} \mathrm{C}$ until PCR was performed (within $48 \mathrm{~h}$ ). Nucleic acid for RT-PCR was extracted from a 140- $\mu 1$ nasopharyngeal sample with a commercial kit (QIAamp Viral RNA mini Kit, QIAGEN AG, Basel, Switzerland) according to the manufacturer's instructions.

RT-PCR for hMPV was performed by use of a one-tube reaction (Titan One Tube RT-PCR System, Roche Diagnostics $\mathrm{GmbH}$ Mannheim, Germany) according to the manufacturer's instructions. Briefly, a primer pair comprising hMPV L-L Hex labeled (5' CAT GCC CAC TAT AAA AGG TCA G $3^{\prime}$ ) and hMPV L-R1 (5' CAC CCC AGT CTT TCT TGA AA $3^{\prime}$ ), amplifying a fragment of $170 \mathrm{bp}$ in the polymerase gene as described by van den Hoogen et al. [37], was used. In addition, a second primer pair hMPV NL1 (5' GCA TGC TAT ATT AAA AGA GTC TCA 3') and hMPV N-R FAM labeled (5' ATC TCA GCA GCA TAT TTG TA 3') was used for amplification of a highly conserved fragment of $157 \mathrm{bp}$ in the nucleoprotein gene. These primers were slightly modified based on those previously described by Maertzdorf at al. [24]. PCR products then were subjected to capillary electrophoresis on an ABI PRISM 310 Genetic Analyzer (Applied Biosystems). Amplified fragments were identified according to fluorescent color (corresponding to the labeled primers) and fragment size within the electropherogram.

As a positive control, RNA of hMPV (subtype A2, according to strain Canada 97/83) was used in every run of PCR (kindly provided by Prof. Dr. D. Neumann-Haefelin, Department of Medical Microbiology and Hygiene, University of Freiburg, Germany). The hMPV was considered present if either hMPV N gene or hMPV L gene or both could be detected.

The two hMPV RT-PCRs were integrated in the existing in-house RT-multiplex PCR as follows: primers for the hMPV N gene were combined with those for RSV, influenza viruses $\mathrm{A}$ and $\mathrm{B}$ (block 1), and primers for HMPV L gene were combined with those for adenoviruses and parainfluenza type 1 and type 3 viruses (block 2) [6, 13, 20, 26, 38]. RNA of RNA viruses was transcribed to cDNA before PCR was performed. PCR techniques were not changed over the course of the study period.

When specifically ordered by the physician, a separate PCR for the detection of Mycoplasma pneumoniae was also performed as described previously by Ieven et al. [17].

\section{Statistical methods}

Data were entered into a database, and statistical analyses were performed using SPSS (version 13.0, SPSS, Inc., Chicago, IL). Clinical characteristics and laboratory variables were compared by Student's $t$-test, Mann-Whitney $U$ test, Fisher's exact test, chi squared test or odds ratio analysis as appropriate. A two-sided $\mathrm{P}$ value of $<0.05$ was considered significant.

\section{Results}

Epidemiological characteristics

During the two winter seasons from 11 October 2004 to 28 February 2006, a total of 2,582 NP specimens were received by our laboratory for PCR tests to detect respiratory pathogens. Based on the physicians' orders for the detection of viruses from multiplex-PCR blocks 1 and 2, 1,500 (58\%) of 2,582 specimens were tested for hMPV: $1,499(58 \%)$ for the hMPV N gene and 1,181 (46\%) for the hMPV L gene $(1,180$ for $\mathrm{N}$ gene and $\mathrm{L}$ gene, 319 for $\mathrm{N}$ gene only and 1 for L gene only). Infection with hMPV was detected in $75(5 \%)$ of 1,500 children, where $74(4.9 \%)$ of 1,499 tested specimens were positive for hMPV $\mathrm{N}$ gene and $29(2.5 \%)$ of 1,181 for hMPV L gene $(\mathrm{p}<0.01)$. Thus, PCR 


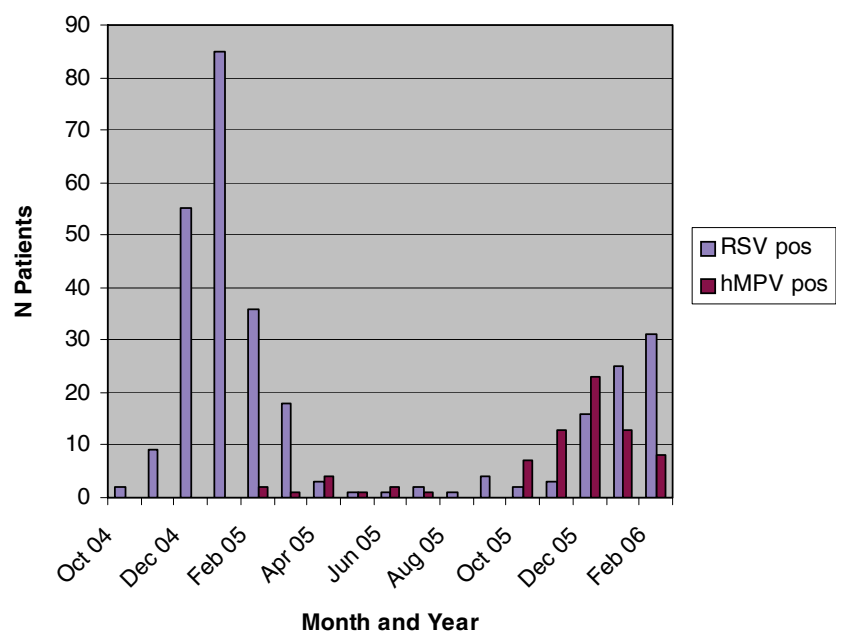

Fig. 1 Numbers and seasonal distribution of RSV and hMPV detected in nasopharyngeal aspirates from patients with respiratory tract infections

for L gene only contributed a single case that would not have been identified by use of N gene PCR primers.

Informed consent and clinical data could be obtained from the parents of $74(99 \%)$ of 75 children infected with hMPV. Whereas only 3 of $691(0.4 \%)$ NP specimens tested for hMPV in the first winter season of this study (October 2004 to March 2005) were positive, the proportion increased to 3.2\% between April and September 2005 (8 of $248 \mathrm{NP}$ specimens positive), and further increased during the following winter season to $11 \%$ (64 hMPV positives among $560 \mathrm{NP}$ specimens). The increase in the proportion of hMPV started in October 2006, reached its peak in December and gradually declined over the next 2 months (Fig. 1).

RSV was detected in 294 (19.5\%) of 1,505 specimens during the same study period with a higher prevalence during the winter season 2004/2005 compared to winter season 2005/ 2006 (Fig. 1). Overall, hMPV and RSV were detected in 14\% and $54 \%$, respectively, of all 520 samples positive for $\geq 1$ respiratory virus by PCR during the study period (Fig. 2).

Five $(7 \%)$ of the $75 \mathrm{hMPV}$-infected patients were documented to be coinfected with other respiratory pathogens: one (1\%) with RSV and four (11\%) with $M$. pneumoniae (of $36 \mathrm{NP}$ specimens tested for both $M$. pneumoniae and $\mathrm{hMPV}$ ).

Clinical characteristics

Patients with hMPV infections were significantly older (mean age 32 months, median 17, interquartile range: 7-44) than RSV-positive patients (mean age 16 months, median 9, interquartile range: $3-17 ; p=0.001)$. Specifically, $29(39 \%)$ of $75 \mathrm{hMPV}$ infections occurred in infants compared with 183 $(62 \%)$ of 294 RSV infections $(p<0.001)$.

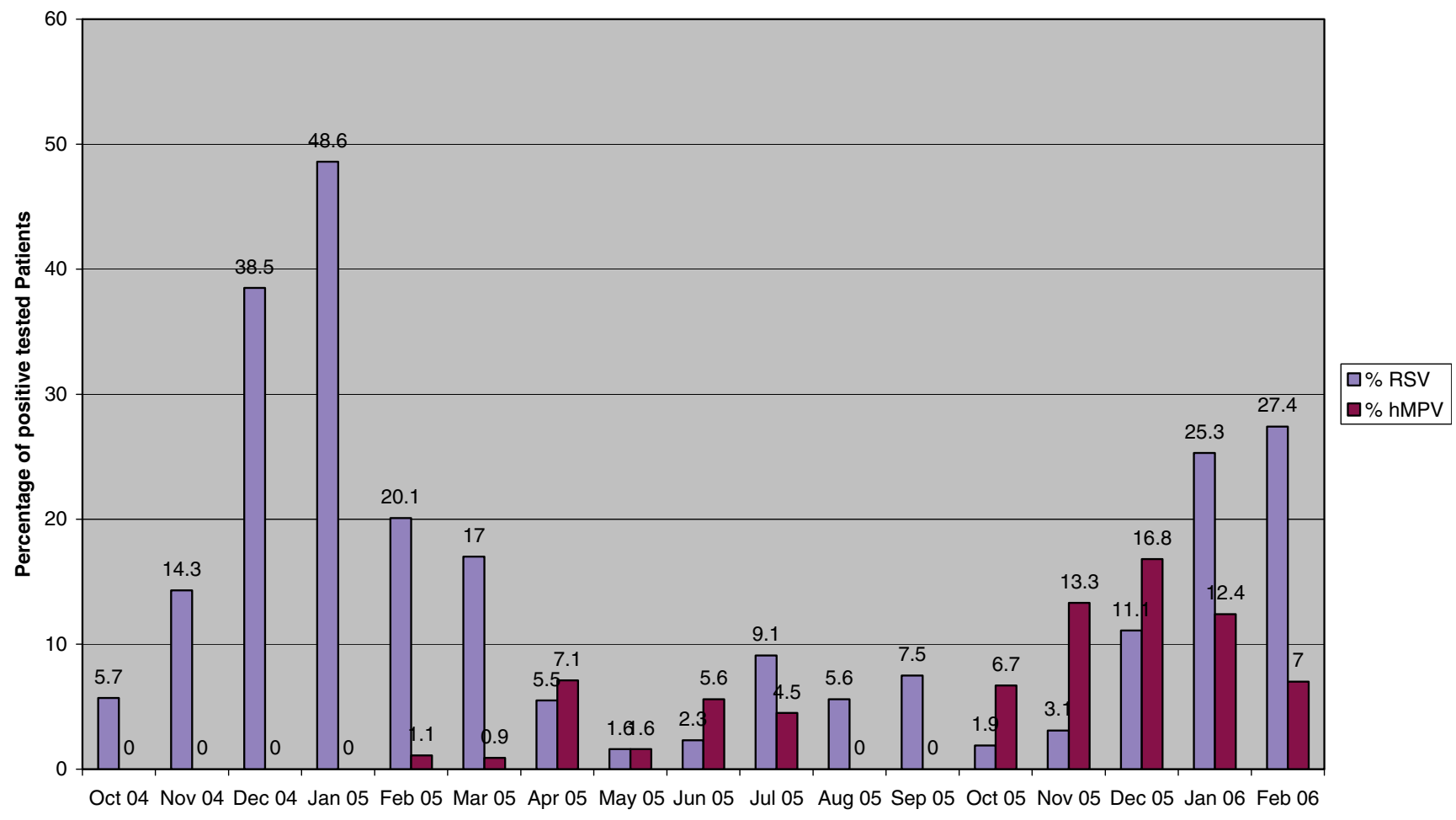

\section{Month and Year}

Fig. 2 Percentage of nasopharyngeal aspirates from patients with respiratory tract infections that tested positive for RSV and hMPV by study month 
Male predominance was more pronounced among children with hMPV infections compared to those with RSV infections (63\% versus 55\%), but this difference was not significant.

Of 75 hMPV-positive children, 34 (45\%) were hospitalized (RSV: 158 of $294 ; 54 \% ; p=0.19)$, and 6 (18\%) of them required intensive-care treatment because of imminent respiratory failure (RSV: 13 of $158 ; 8 \% ; \mathrm{p}=0.095)$. The remaining 41 patients were treated as outpatients. Of the six patients requiring intensive care, two had co-infections of hMPV and a further respiratory pathogen: one 17.8-year-old girl with trisomy 21 , congenital heart disease and infectionassociated hepatitis and myocarditis was co-infected with M. pneumoniae; she needed mechanical ventilation for 8 days and supportive oxygen therapy for 24 consecutive days. Furthermore, a 1-month-old boy was co-infected with $\mathrm{RSV}$ and also recovered on intensive care treatment.
A summary of clinical characteristics of hMPV infections and a comparison between hospitalized children and outpatients are demonstrated in Table 1. Mean duration of hospitalization for community-acquired hMPV infections was $6.6 \pm 8.9$ days (median 4 , interquartile range 2-6). One patient acquired a nosocomial hMPV infection. He had a VACTERL association and developed respiratory symptoms on day 46 from which he recovered. Subsequently, however, he also acquired parainfluenza virus infection and finally died on day 106 due to his underlying condition. No other deaths in hMPV-positive patients occurred.

Dyspnea, need for oxygen supplementation and feeding difficulties or loss of appetite were the only characteristics that were more frequent among hospitalized children who also tended to be younger than outpatients. Most of the patients with hMPV infections had LRTI $(n=57 ; 77 \%)$, and this was true for both in- and outpatients. Age distribution

Table 1 Comparison of clinical characteristics of hospitalized and outpatients with hMPV infections

\begin{tabular}{|c|c|c|c|c|c|}
\hline Clinical characteristics & $\begin{array}{l}\text { Total }^{\mathrm{a}} \\
\mathrm{n}=75(\%)\end{array}$ & $\begin{array}{l}\text { Outpatients }^{\mathrm{a}} \\
\mathrm{n}=41(\%)\end{array}$ & $\begin{array}{l}\text { Hospitalized patients; } \\
\mathrm{n}=34(\%)\end{array}$ & $P$ value ${ }^{b}$ & OR $(95 \% \mathrm{CI})$ \\
\hline Age in months (mean \pm SD) & $31.7 \pm 38.9$ & $35.6 \pm 38.7$ & $27 \pm 39.3$ & & Not applicable \\
\hline Male gender & $47 / 75(63)$ & $26 / 41(63)$ & $21 / 34(62)$ & & $1.07(0.42-2.75)$ \\
\hline Prematurity & $8 / 61^{\mathrm{c}}(13)$ & $4 / 27^{c}(15)$ & $4 / 34(12)$ & & $0.77(0.17-3.40)$ \\
\hline Body temperature $37.1-38.4^{\circ} \mathrm{C}$ & $17 / 74(23)$ & $9 / 40(23)$ & $8 / 34(24)$ & & Not applicable \\
\hline$\geq 38.5-38.9^{\circ} \mathrm{C}$ & $14 / 74(19)$ & $12 / 40(30)$ & $2 / 34(6)$ & & Not applicable \\
\hline$\geq 39^{\circ} \mathrm{C}$ & $43 / 74(58)$ & $19 / 40(48)$ & $24 / 34(71)$ & & Not applicable \\
\hline Cough & 73/74 (99) & $39 / 40(98)$ & $34 / 34(100)$ & & Not applicable \\
\hline Dyspnea & $34 / 74(46)$ & $11 / 40(28)$ & $23 / 34(68)$ & 0.001 & $5.51(2.03-14.97)$ \\
\hline Wheezing & $34 / 74(46)$ & $15 / 40(36)$ & $23 / 34(68)$ & & $2.11(0.83-5.36)$ \\
\hline URTI & $65 / 74(88)$ & $33 / 40(83)$ & $32 / 34(94)$ & & $3.39(0.66-17.58)$ \\
\hline - Conjunctivitis & $7 / 74(9)$ & $2 / 40(5)$ & $5 / 34(15)$ & & $3.28(0.59-18.10)$ \\
\hline - Rhinitis & $58 / 74(78)$ & $29 / 40(73)$ & $29 / 34(85)$ & & $2.20(0.68-7.13)$ \\
\hline - Pharyngitis & $34 / 74(46)$ & $16 / 40(40)$ & $18 / 34(53)$ & & $1.69(0.67-4.25)$ \\
\hline - AOM & $10 / 74(14)$ & $7 / 40(18)$ & $3 / 34(9)$ & & $0.46(0.10-1.92)$ \\
\hline$L R T I^{\mathrm{d}}$ & $57 / 74(77)$ & $30 / 40(75)$ & $27 / 34(79)$ & & $1.29(0.43-3.85)$ \\
\hline - Pneumonia & $25 / 74(34)$ & $10 / 40(25)$ & $15 / 34(44)$ & & $2.37(0.88-6.34)$ \\
\hline - Bronchitis & $34 / 74(46)$ & $21 / 40(51)$ & $13 / 34(38)$ & & $0.56(0.22-1.42)$ \\
\hline - Bronchiolitis & $13 / 74(18)$ & $5 / 40(13)$ & $8 / 34(24)$ & & $2.15(0.63-7.35)$ \\
\hline - Croup & $5 / 74(8)$ & $2 / 40(5)$ & $3 / 34(9)$ & & $1.84(0.29-11.71)$ \\
\hline Exanthema & $8 / 74(11)$ & $3 / 40(8)$ & $5 / 34(15)$ & & $2.13(0.47-9.64)$ \\
\hline Feeding difficulties/loss of appetite & $26 / 74(35)$ & $9 / 40(23)$ & $17 / 34(50)$ & 0.014 & $3.44(1.26-9.38)$ \\
\hline Vomiting & $25 / 74(34)$ & $13 / 40(33)$ & $12 / 34(35)$ & & $1.13(0.43-2.97)$ \\
\hline Concomitant diarrhea & $19 / 74(26)$ & $14 / 40(35)$ & $5 / 34(15)$ & 0.046 & $0.32(0.10-1.01)$ \\
\hline \multicolumn{6}{|l|}{ Treatment } \\
\hline - Antibiotics & $38 / 74(51)$ & $19 / 40(48)$ & $19 / 34(56)$ & & $1.40(0.56-3.51)$ \\
\hline - Oral steroids & $9 / 74(12)$ & $1 / 40(3)$ & $8 / 34(24)$ & 0.017 & $12.0(1.42-101.7)$ \\
\hline - Inhalative therapy & $27 / 74(36)$ & $7 / 40(18)$ & $20 / 34(59)$ & 0.001 & $6.73(2.32-19.5)$ \\
\hline - Bronchodilatator & $20 / 74(27)$ & $5 / 40(13)$ & $15 / 34(44)$ & 0.003 & Not applicable \\
\hline - Bronchodilatator/steroids & $7 / 74(9)$ & $2 / 40(5)$ & $5 / 34(15)$ & 0.003 & Not applicable \\
\hline - Oxygen therapy & $13 / 74(18)$ & $0 / 40(0)$ & $13 / 34(38)$ & $<0.0001$ & Not applicable \\
\hline
\end{tabular}

${ }^{\text {a }}$ Data on most characteristics are missing for one outpatient due to lack of parental consent

${ }^{\mathrm{b}}$ If $<0.05$

${ }^{\mathrm{c}}$ Data on 14 patients missing due to lack of documentation $(n=13)$ or lack of parental consent $(n=1)$

${ }^{\mathrm{d}}$ More than one diagnosis of LRTI was made in some patients 
was similar between patients with LRTI and those with URTI only (data not shown). Interestingly, though, children with pneumonia were significantly older than those with other manifestations of respiratory tract disease (mean $46.9 \pm$ 47.2 months and $24.5 \pm 32.2$ months, respectively; $p=0.04$ ).

Three children-17, 19 and 36 months old-presented with a febrile convulsion, and one further patient experienced a relapse of nephrotic syndrom while suffering from hMPV infection. Twenty-two (30\%) of $74 \mathrm{hMPV}$ infected children had various forms of underlying chronic disease and 15 $(68 \%)$ of them were hospitalized compared with 19 (37\%) of 52 primary healthy children $(p=0.03)$.

\section{Discussion}

Human metapneumovirus, a member of the Paramyxoviridiae family, is a single-stranded negative-sense RNA virus that was first described by Dutch investigators, who isolated the virus from young children with RTI [36]. Here we report the first description of a large number of hMPV infections in children in Switzerland and provide a detailed description of epidemiological and clinical characteristics.

During the 2-year study period the detection rate steadily increased from $0.4 \%$ (months $1-6$ ) to $3.2 \%$ (months $7-12$ ) and finally reached a proportion as high as $11 \%$ of tested NP samples being hMPV positive (months 13-17). Whether this represents a pattern of biannual major epidemics similar to those observed with RSV remains to be seen [2, 10, 39]. Previous reports of hMPV infections from various countries have described a characteristic seasonality with peaks during the cold seasons $[9,15,18,34,42]$, but none of these studies was performed over a prolonged period of time. Similarly, we observed an impressive peak during winter 2005/2006, and we will continue our observations in order to better define the seasonality of hMPV infections in the future.

The overall detection rate for $\mathrm{hMPV}$ in this study was $5 \%$, which is in the lower range of rates that have been detected among children with acute RTIs in previous investigations from Europe, North and South America, South Africa, Australia and Asia, most of them restricted to hospitalized patients, i.e., 5 to $16 \%[8,12,19,21,27,30,31,42]$. Studies with detection rates in the upper range usually were restricted to winter seasons when peaks of infections occur. In contrast, those with rates in the lower range frequently also covered summer months (which necessarily leads to a lower percentage of detection), like our study, which was uninterrupted for 17 consecutive months.

Although no viral cultures were performed to assess the overall sensitivity of PCR tests in this study, PCR based on $\mathrm{N}$ gene primers was more sensitive than PCR based on $\mathrm{L}$ gene primers. In a comparative evaluation of real-time PCR assays for the detection of $\mathrm{hMPV}, \mathrm{N}$ and $\mathrm{L}$ gene primers were shown to be most suitable, and sensitivity of $\mathrm{N}$ gene primers was superior to that of $\mathrm{L}$ gene primers, which is in accordance with our findings [7]. Given the fact that the additional use of $\mathrm{L}$ gene primers contributed only minimally to the overall sensitivity of PCR for hMPV in our study, it appears that the use of $\mathrm{N}$ gene primers alone is sufficient.

The presenting signs and symptoms of hMPV infection are reminiscent of those associated with RSV [25]. However, hMPV-infected patients were significantly older than RSV-infected patients in this study, which is consistent with findings in the literature [30, 37, 42, 43]. Moreover, despite the fact that both viruses mainly circulate during the winter season, we identified only a single patient with dual hMPV and RSV infection. This underlines the notion that both viruses independently cause similar infections [37].

When comparing the clinical presentation of hospitalized hMPV-infected patients with those of outpatients, hospitalized patients tended to be younger and more frequently suffered from dyspnea and feeding difficulties or loss of appetite. Interestingly, $77 \%$ of hMPV-infected patients suffered from LRTI. This was not different between hospitalized and outpatients, which may be explained by the retrospective design of our study where outpatients with more serious disease probably had been selected for diagnostic testing. However, wheezing tended to be more frequent among hospitalized children (68\%). Consequently, $38 \%$ of them needed oxygen supplementation (compared to none of the outpatients), and steroids and bronchodilators were also used more frequently in hospitalized children than in outpatients. Although this was a retrospective analysis open to the introduction of bias, these differences are quite plausible.

Approximately $50 \%$ of patients received antibiotics during some stage of their illness, and this rate appears to be high. However, in most instances antibiotic treatment was prompted by concomitant pneumonia or acute otitis media where secondary bacterial infections apparently were suspected and/or the presence of hMPV infection was not yet known. Similarly, $60 \%$ of hospitalized children with hMPV infection were treated with antibiotics in the Netherlands, a country with a restrictive policy for the use of antibiotics like in Switzerland [37].

Thirty percent of hMPV-infected patients had chronic underlying diseases, and $11 \%$ had a history of prematurity, similar to previous observations $[4,12,37,40]$. This may be an indication for increased susceptibility in these hosts and/ or an artifact explained by the fact that physicians are more likely to order diagnostic tests in these high-risk patients.

There are conflicting results concerning whether dual infections by hMPV and other respiratory tract viruses, mainly RSV, are associated with a more severe disease than that observed with hMPV as the single etiological cause of disease. Semple et al. reported a tenfold increase in the 
relative risk of admission to a pediatric intensive-care unit for mechanical ventilation due to severe bronchiolitis in patients with dual infection with hMPV and RSV [35]. Similarly, dual infections with hMPV and RSV were found in $70 \%$ of infants with severe bronchiolitis admitted to a pediatric intensive-care unit for mechanical ventilation [16]. This is further supported by other recent data mainly in children less than 3 years of age [14, 22]. In contrast, other studies have failed to demonstrate more serious disease with dual infections $[5,15,23,40,41,43]$. Although we only found a single patient with hMPV and RSV coinfection, this infant required intensive care treatment. Larger studies are needed to elucidate whether-and if so by which mechanisms-hMPV and RSV co-infection leads to a more serious course of respiratory disease or not.

Acknowledgement We would like to specially thank the following pediatricians in private practice for obtaining informed consent and providing clinical data from patients with hMPV infections: A. Amacher, D. Ambühl-Stamm, D. Guldimann, M. Hürlimann, H. Hug-Batschelet, S. Isay-Utzinger, F. Hadziselimovic, C. Kaymak, Ch. Klimm, I. Müller, F. Nicola, C. Teelmann-Seebas and C. Wandt.

We are grateful to the medical staff at the University Children's Hospital Basel for obtaining NP specimens from patients and to S. Balogh, E. Dertschnig, J. Glaus, C. Möller and R. Hertel for performing the PCR assays.

\section{References}

1. Al-Sonboli N, Hart CA, Al-Aeryani A, Banajeh SM, Al-Aghbari N, Dove W, Cuevas LE (2005) Respiratory syncytial virus and human metapneumovirus in children with acute respiratory infections in Yemen. Pediatr Infect Dis J 24:734-736

2. Berner R, Schwoerer F, Schumacher RF, Meder M, Forster J (2001) Community and nosocomially acquired respiratory syncytial virus infection in a German paediatric hospital from 1988 to 1999. Eur J Pediatr 160:541-547

3. Boivin G, Abed Y, Pelletier G, Ruel L, Moisan D, Cote S, Peret TC, Erdman DD, Anderson LJ (2002) Virological features and clinical manifestations associated with human metapneumovirus: A new paramyxovirus responsible for acute respiratory-tract infections in all age groups. J Infect Dis 186:1330-1334

4. Boivin G, De Serres G, Cote S, Gilca R, Abed Y, Rochette L, Bergeron MG, Dery P (2003) Human metapneumovirus infections in hospitalized children. Emerg Infect Dis 9:634-640

5. Bosis S, Esposito S, Niesters HG, Crovari P, Osterhaus AD, Principi N (2005) Impact of human metapneumovirus in childhood: Comparison with respiratory syncytial virus and influenza viruses. J Med Virol 75:101-104

6. Claas EC, Sprenger MJ, Kleter GE, van Beek R, Quint WG, Masurel N (1992) Type-specific identification of influenza viruses $\mathrm{a}, \mathrm{b}$ and $\mathrm{c}$ by the polymerase chain reaction. J Virol Methods 39:1-13

7. Cote S, Abed Y, Boivin G (2003) Comparative evaluation of realtime PCR assays for detection of the human metapneumovirus. J Clin Microbiol 41:3631-3635

8. Cuevas LE, Nasser AM, Dove W, Gurgel RQ, Greensill J, Hart CA (2003) Human metapneumovirus and respiratory syncytial virus, Brazil. Emerg Infect Dis 9:1626-1628
9. Dollner H, Risnes K, Radtke A, Nordbo SA (2004) Outbreak of human metapneumovirus infection in Norwegian children. Pediatr Infect Dis 23:436-440

10. Duppenthaler A, Gorgievski-Hrisoho M, Frey U, Aebi C (2003) Two-year periodicity of respiratory syncytial virus epidemics in Switzerland. Infection 31:75-80

11. Ebihara T, Endo R, Kikuta H, Ishiguro N, Yoshioka M, Ma X, Kobayashi K (2003) Seroprevalence of human metapneumovirus in Japan. J Med Virol 70:281-283

12. Esper F, Martinello RA, Boucher D, Weibel C, Ferguson D, Landry ML, Kahn JS (2004) A 1-year experience with human metapneumovirus in children aged $<5$ years. J Infect Dis 189:1388-1396

13. Fan J, Henrickson KJ (1996) Rapid diagnosis of human parainfluenza virus type 1 infection by quantitative reverse transcriptionPCR-enzyme hybridization assay. J Clin Microbiol 34:1914-1917

14. Foulongne V, Guyon G, Rodiere M, Segondy M (2006) Human metapneumovirus infection in young children hospitalized with respiratory tract disease. Pediatr Infect Dis J 25:354-359

15. Garcia-Garcia ML, Calvo C, Martin F, Perez-Brena P, Acosta B, Casas I (2006) Human metapneumovirus infections in hospitalised infants in Spain. Arch Dis Child 91:290-295

16. Greensill J, McNamara PS, Dove W, Flanagan B, Smyth RL, Hart CA (2003) Human metapneumovirus in severe respiratory syncytial virus bronchiolitis. Emerg Infect Dis 9:372-375

17. Ieven M, Ursi D, Van Bever H, Quint W, Niesters HG, Goossens H (1996) Detection of mycoplasma pneumoniae by two polymerase chain reactions and role of $M$. Pneumoniae in acute respiratory tract infections in pediatric patients. J Infect Dis 173:1445-1452

18. Jartti T, Lehtinen P, Vuorinen T, Osterback R, van den Hoogen B, Osterhaus AD, Ruuskanen O (2004) Respiratory picornaviruses and respiratory syncytial virus as causative agents of acute expiratory wheezing in children. Emerg Infect Dis 10:1095-1101

19. Jartti $T$, van den Hoogen $B$, Garofalo RP, Osterhaus AD, Ruuskanen O (2002) Metapneumovirus and acute wheezing in children. Lancet 360:1393-1394

20. Karron RA, O'Brien KL, Froehlich JL, Brown VA (1993) Molecular epidemiology of a parainfluenza type 3 virus outbreak on a pediatric ward. J Infect Dis 167:1441-1445

21. Kim YK, Lee HJ (2005) Human metapneumovirus-associated lower respiratory tract infections in Korean infants and young children. Pediatr Infect Dis J 24:1111-1112

22. Konig B, Konig W, Arnold R, Werchau H, Ihorst G, Forster J (2004) Prospective study of human metapneumovirus infection in children less than 3 years of age. J Clin Microbiol 42:4632-4635

23. Lazar I, Weibel C, Dziura J, Ferguson D, Landry ML, Kahn JS (2004) Human metapneumovirus and severity of respiratory syncytial virus disease. Emerg Infect Dis 10:1318-1320

24. Maertzdorf J, Wang CK, Brown JB, Quinto JD, Chu M, de Graaf M, van den Hoogen BG, Spaete R, Osterhaus AD, Fouchier RA (2004) Real-time reverse transcriptase PCR assay for detection of human metapneumoviruses from all known genetic lineages. J Clin Microbiol 42:981-986

25. Meury S, Zeller S, Heininger U (2004) Comparison of clinical characteristics of influenza and respiratory syncytial virus infection in hospitalised children and adolescents. Eur J Pediatr 163:359-363

26. Morris DJ, Cooper RJ, Barr T, Bailey AS (1996) Polymerase chain reaction for rapid diagnosis of respiratory adenovirus infection. J Infect 32:113-117

27. Morrow BM, Hatherill M, Smuts HE, Yeats J, Pitcher R, Argent AC (2006) Clinical course of hospitalised children infected with human metapneumovirus and respiratory syncytial virus. J Pediatr Child Health 42:174-178

28. Nicholson KG, McNally T, Silverman M, Simons P, Stockton JD, Zambon MC (2006) Rates of hospitalisation for influenza, 
respiratory syncytial virus and human metapneumovirus among infants and young children. Vaccine 24:102-108

29. Nissen MD, Siebert DJ, Mackay IM, Sloots TP, Withers SJ (2002) Evidence of human metapneumovirus in Australian children. Med J Aust 176:188

30. Peiris JS, Tang WH, Chan KH, Khong PL, Guan Y, Lau YL, Chiu SS (2003) Children with respiratory disease associated with metapneumovirus in Hong Kong. Emerg Infect Dis 9:628-633

31. Peret TC, Boivin G, Li Y, Couillard M, Humphrey C, Osterhaus AD, Erdman DD, Anderson LJ (2002) Characterization of human metapneumoviruses isolated from patients in North America. J Infect Dis 185:1660-1663

32. Regev L, Hindiyeh M, Shulman LM, Barak A, Levy V, Azar R, Shalev Y, Grossman Z, Mendelson E (2006) Characterization of human metapneumovirus infections in Israel. J Clin Microbiol 44:1484-1489

33. Samransamruajkit R, Thanasugarn W, Prapphal N, Theamboonlers A, Poovorawan Y (2006) Human metapneumovirus in infants and young children in Thailand with lower respiratory tract infections; molecular characteristics and clinical presentations. J Infect 52:254-263

34. Schildgen O, Geikowski T, Glatzel T, Schuster J, Simon A (2005) Frequency of human metapneumovirus in the upper respiratory tract of children with symptoms of an acute otitis media. Eur J Pediatr 164:400-401

35. Semple MG, Cowell A, Dove W, Greensill J, McNamara PS, Halfhide C, Shears P, Smyth RL, Hart CA (2005) Dual infection of infants by human metapneumovirus and human respiratory syncytial virus is strongly associated with severe bronchiolitis. J Infect Dis 191:382-386

36. van den Hoogen BG, de Jong JC, Groen J, Kuiken T, de Groot R, Fouchier RA, Osterhaus AD (2001) A newly discovered human pneumovirus isolated from young children with respiratory tract disease. Nat Med 7:719-724
37. van den Hoogen BG, van Doornum GJ, Fockens JC, Cornelissen JJ, Beyer WE, de Groot R, Osterhaus AD, Fouchier RA (2003) Prevalence and clinical symptoms of human metapneumovirus infection in hospitalized patients. J Infect Dis 188:1571-1577

38. van Milaan AJ, Sprenger MJ, Rothbarth PH, Brandenburg AH, Masurel N, Claas EC (1994) Detection of respiratory syncytial virus by RNA-polymerase chain reaction and differentiation of subgroups with oligonucleotide probes. J Med Virol 44:80-87

39. Weigl JA, Puppe W, Schmitt HJ (2002) Seasonality of respiratory syncytial virus-positive hospitalizations in children in Kiel, Germany, over a 7-year period. Infection 30:186-192

40. Wilkesmann A, Schildgen O, Eis-Hubinger AM, Geikowski T, Glatzel T, Lentze MJ, Bode U, Simon A (2006) Human metapneumovirus infections cause similar symptoms and clinical severity as respiratory syncytial virus infections. Eur J Pediatr $165: 467-475$

41. Williams JV, Harris PA, Tollefson SJ, Halburnt-Rush LL, Pingsterhaus JM, Edwards KM, Wright PF, Crowe JE Jr (2004) Human metapneumovirus and lower respiratory tract disease in otherwise healthy infants and children. N Engl J Med 350:443450

42. Williams JV, Wang CK, Yang CF, Tollefson SJ, House FS, Heck JM, Chu M, Brown JB, Lintao LD, Quinto JD, Chu D, Spaete RR, Edwards KM, Wright PF, Crowe JE Jr (2006) The role of human metapneumovirus in upper respiratory tract infections in children: a 20-year experience. J Infect Dis 193:387-395

43. Wolf DG, Greenberg D, Kalkstein D, Shemer-Avni Y, Givon-Lavi N, Saleh N, Goldberg MD, Dagan R (2006) Comparison of human metapneumovirus, respiratory syncytial virus and influenza a virus lower respiratory tract infections in hospitalized young children. Pediatr Infect Dis J 25:320-324

44. Wolf DG, Zakay-Rones Z, Fadeela A, Greenberg D, Dagan R (2003) High seroprevalence of human metapneumovirus among young children in Israel. J Infect Dis 188:1865-1867 